Zeszyty Naukowe Szkoły Głównej Gospodarstwa Wiejskiego w Warszawie Problemy Rolnictwa Światowego tom 17 (XXXII), zeszyt 2, 2017: 126-135

DOI: $10.22630 /$ PRS.2017.17.2.32

Lukasz Kozar ${ }^{1}$

Uniwersytet Łódzki

\title{
Produkcja energii elektrycznej ze źródeł odnawialnych w krajach Unii Europejskiej i w Polsce w kontekście koncepcji zrównoważonego rozwoju ${ }^{2}$
}

\section{Production of Electricity from Renewable Sources in Countries of the European Union and Poland in the Context of the Concept of Sustainable Development}

\begin{abstract}
Synopsis. W artykule przedstawiono zmiany jakie nastapiły w zakresie produkcji energii elektrycznej z odnawialnych źródeł energii w krajach UE-28 oraz w Polsce w latach 2010-2015. Analize zmian przeprowadzono na podstawie danych z Eurostatu oraz Banku Danych Lokalnych. W oparciu o wskaźnik określający udział energii elektrycznej wytwarzanej ze źródeł odnawialnych w zużyciu energii elektrycznej brutto wykazano, iż Polska charakteryzowała się w omawianym okresie jedna z najwyższych dynamik zmian spośród wszystkich państw UE. Ponadto $w$ artykule zanalizowano sytuację dotycząca produkcji energii elektrycznej w Polsce w przekroju regionalnym. Z podjętych w tym zakresie analiz wynika, iż we wszystkich województwach oprócz małopolskiego w $2015 \mathrm{r}$. produkowano więcej energii elektrycznej ze źródeł odnawialnych w porównaniu do $2010 \mathrm{r}$. W omawianym okresie również o $99 \%$ wzrósł w Polsce udział produkcji energii elektrycznej ze źródeł odnawialnych w produkcji energii elektrycznej ogółem.
\end{abstract}

Slowa kluczowe: zrównoważony rozwój, Unia Europejska, odnawialne źródła energii

\begin{abstract}
The article presents changes that occurred in the production of electricity from renewable energy sources in the EU-28 and in Poland in the years of 2010-2015. The analysis of the changes was based on the data from Eurostat and the Local Data Bank. Based on the indicator of the share of electricity generated from renewable sources in gross electricity consumption, Poland in the period under discussion, was characterized as one of the highest dynamics of change among all EU countries. In addition, the article analyzes the situation concerning the production of electricity in Poland in the regional aspect. From the taken analyzes, it is clear that in all voivodeships, apart from Małopolskie voivodeship, in 2015, more electricity was produced from renewable sources compared to 2010 . In the period under discussion, the share of electricity production from renewable sources in total electricity production also increased by $99 \%$ in Poland.
\end{abstract}

Key words: sustainable development, European Union, renewable energy sources

\section{Wprowadzenie}

Współczesny świat w wymiarze zarówno gospodarczym, środowiskowym, jak i społecznym boryka się z licznymi problemami. Wśród nich istotne miejsce zajmuje problematyka związana $z$ dostępem do odpowiednich źródeł energii oraz wyborem sposobu

${ }^{1}$ mgr, Katedra Pracy i Polityki Społecznej, Instytut Ekonomik Stosowanych i Informatyki Uniwersytet Łódzki, ul. Rewolucji 1905 r.nr 39,90-214 Łódź, e-mail: kozarlukasz@gmail.com

${ }^{2}$ Publikacja finansowana $\mathrm{w}$ ramach dotacji z środków na badania własne młodych naukowców i uczestników studiów doktoranckich - kod projektu B1711200001654.02 
jej produkcji (Malko i in., 2015). Dostęp taki zróżnicowany jest przestrzennie przede wszystkim naturalnymi uwarunkowaniami występowania złóż surowców energetycznych (Lior, 2008; Ang i in., 2015). Dodatkowo podkreśla się konieczność zaspokojenia wciąż rosnącego wraz z postępującym rozwojem cywilizacyjnym zapotrzebowania na energię (Suppes i Storvick, 2016). Wychodzenie naprzeciw oczekiwaniom społecznym oraz gospodarczym w tym zakresie przyczynia się $\mathrm{z}$ jednej strony do stopniowego wyczerpywania się paliw kopalnych (węgla, ropy naftowej, czy też gazu ziemnego). Z drugiej zaś strony korzystanie ze wskazanych wyżej nieodnawialnych źródeł w procesie produkcji energii skutkuje znacznym wzrostem zanieczyszczenia środowiska naturalnego, głównie poprzez emisję różnego rodzaju pyłów oraz gazów wywołujących efekt cieplarniany do atmosfery (Qureshi i in., 2016; Zaman i Abd-el Moemen, 2017).

Przytoczone argumenty pozwalają stwierdzić, iż problematyka dostępu do surowców energetycznych jest bardzo złożona. Niemniej jednak coraz częściej, w obliczu negatywnych skutków wykorzystania konwencjonalnych źródeł energii oraz ich stopniowego wyczerpywania się, uwagę zwraca się na odnawialne źródła energii (OZE). Należy tutaj wskazać, iż zasoby takich alternatywnych $\mathrm{w}$ stosunku do nieodnawialnych źródeł energii uzupełniają się $w$ naturalnych procesach. Przy czym błędem jest podkreślanie, iż są niewyczerpywalne, gdyż zawsze może dojść do hipotetycznej sytuacji, która może spowodować, iż takie źródło energii ulegnie wyczerpaniu (Twidell i Weir, 2015). Niemniej jednak wzrost wykorzystania OZE nieść może wiele pozytywnych rezultatów. Jednym z nich może być stopniowy spadek wysokiej szkodliwości działalności sektora energetycznego na środowisko naturalne (ograniczenie emisji szkodliwych substancji, zwłaszcza już wspominanych pyłów oraz gazów cieplarnianych). Ponadto wzrost zainteresowania OZE przyczynia się do stopniowego rozwoju technologicznego tego sektora (Szałata i in., 2016). W konsekwencji następuje spadek kosztów wytwarzania energii ze źródeł odnawialnych (wzrost opłacalności produkcji), a sektor odnawialnych źródeł energii staje się coraz poważniejszą alternatywą wobec źródeł konwencjonalnych.

W sposób szczególny na konieczność wzrostu wykorzystania źródeł odnawialnych we współczesnej gospodarce zwraca uwagę Komisja Europejska w Strategii Europa 2020 (Europa 2020. Strategia..., 2010). W dokumencie tym podkreśla się, iż dotychczasowy sposób gospodarowania zawiódł, a więc potrzebne staje się wypracowanie nowego modelu gospodarczego w znacznie szerszym stopniu nawiązującego do troski o otaczające nas środowisko naturalne. Stąd też coraz częściej mówi się o konieczności dążenia do zrównoważonego rozwoju, czyli takiego stanu rozwoju, który cechować ma się docelowo ukształtowaniem równowagi pomiędzy wzrostem gospodarczym, społecznym oraz problemami związanymi z zachowaniem środowiska przyrodniczego i dóbr naturalnych dla przyszłych pokoleń w takim stanie, aby móc zagwarantować im w przyszłości rozwój przynajmniej na tożsamym poziomie (Poskrobko, 2009). Osiągnięcie takiego stanu równowagi jest jednak kwestią bliżej nieokreślonej przyszłości. Dzieje się tak, gdyż w tym zakresie konieczna jest współpraca ze sobą wielu państw oraz organizacji międzynarodowych w celu zapewnienia wspólnych, wzajemnie się nie wykluczających działań mających na celu wypracowanie rozwiązań minimalizujących negatywny wpływ podejmowanych działalności gospodarczych na środowisko naturalne. Ponadto $\mathrm{w}$ procesie takich przemian niezmiernie ważne staje się odpowiednie wpłynięcie na zmianę świadomości konsumentów. To od wzorca konsumpcji w dużej mierze będzie zależało tempo zmian społeczno-gospodarczych ukierunkowanych na zrównoważony rozwój. 
Działania wyżej wymienione są obecnie w sposób szczególny realizowane na obszarze państw członkowskich Unii Europejskiej poprzez wspieranie budowania tzw. zielonej gospodarki, której istotnym elementem jest wzrost wykorzystania w końcowym zużyciu energii ze źródeł odnawialnych (Ryszawska, 2013). Takiemu ukierunkowaniu gospodarki sprzyja w szczególności Strategia Europa 2020, w której zdefiniowano najważniejsze wyzwania, przed jakimi stoją państwa członkowskie UE na drodze do zrównoważonego rozwoju. Wśród nich pojawia się problematyka związana z energią z odnawialnych źródeł (postawiony cel w myśl którego w 2020 r. przynajmniej 20\% pozyskiwanej energii powinno pochodzić ze źródeł odnawialnych). W tym miejscu należy nadmienić, iż znacząca część pozyskiwanej energii to powszechnie wykorzystywana niemalże przez każdego uczestnika życia społeczno-gospodarczego energia elektryczna. Stąd też za cel artykułu wyznaczono ukazanie zmian produkcji energii elektrycznej ze źródeł odnawialnych w krajach Unii Europejskiej oraz w Polsce jakie zaszły w latach 2010-2015 (pierwszych pięciu latach obowiązywania strategii Europa 2020).

\section{Materiał i metodyka badań}

Dla rozpoznania przyjętego w niniejszym artykule problemu badawczego wykorzystano dane Urzędu Statystycznego Unii Europejskiej (Eurostat) oraz Banku Danych Lokalnych (BDL). Badaniem zostały objęte wszystkie kraje członkowskie UE. Szczególny nacisk w podjętych analizach został ukierunkowany na przedstawienie sytuacji Polski w zakresie produkcji energii elektrycznej ze źródeł odnawialnych. W tym przypadku została omówiona sytuacja między poszczególnymi województwami. W opracowaniu zastosowano metodę analizy opisowej, która została wsparta tabelaryczną prezentacją danych. Ponadto przy prezentacji danych posłużono się wskaźnikami dynamiki, które pozwoliły na zobrazowanie zmian, jakie zaszły $\mathrm{w}$ aspekcie produkcji energii elektrycznej ze źródeł odnawialnych w latach 2010-2015 zarówno na obszarze państw UE, jak i w poszczególnych województwach w Polsce.

\section{Analiza sytuacji Polski na tle państw Unii Europejskiej w zakresie produkcji energii elektrycznej ze źródeł odnawialnych}

Wzrost udziału energii ze źródeł odnawialnych w końcowym zużyciu energii brutto jest jednym z kluczowych celów Unii Europejskiej sformułowanych w Strategii Europa 2020. W dokumencie tym podkreśla się, iż w 2020 roku udział ten w skali całej UE powinien wynosić co najmniej $20 \%$. Tak określony parametr mający stopniowo przybliżać UE do zrównoważonego rozwoju $\mathrm{w}$ zakresie wykorzystania energii został przełożony na cele poszczególnych krajów członkowskich. Cele krajowe nie oznaczają wprost podziału obciążeń. Należy zaznaczyć, iż każdy kraj członkowski UE rozpoczął realizację Strategii Europa 2020 z innej pozycji wyjściowej (uwarunkowanej sytuacją społeczno-gospodarczą), w związku z czym cele na rok 2020 wyznaczono dla każdego indywidualnie. Dzięki temu każde z państw może przyczyniać się solidarnie, według swoich możliwości, do osiagnięcia wyznaczonego ogólnounijnego celu (tab. 1). 
Tabela 1. Udział energii ze źródeł odnawialnych w końcowym zużyciu energii brutto w \% w państwach UE-28 w latach 2010-2015

Table 1. Share of energy from renewable sources in gross final energy consumption in \% in EU-28 in 2010-2015

\begin{tabular}{|c|c|c|c|c|c|c|c|c|c|c|}
\hline \multirow[t]{2}{*}{ Wyszczególnienie } & \multicolumn{6}{|c|}{$\begin{array}{l}\text { Udział energii ze źródeł odnawialnych } \\
\text { w końcowym zużyciu energii brutto w \% w roku: }\end{array}$} & \multirow[t]{2}{*}{$Z_{\text {miana }}{ }^{1}$} & \multirow[t]{2}{*}{$\mathrm{I}_{\mathrm{t} / 1}^{2}$} & \multirow{2}{*}{$\begin{array}{c}\text { Cel } \\
2020^{3}\end{array}$} & \multirow[t]{2}{*}{ Różnica $^{4}$} \\
\hline & 2010 & 2011 & 2012 & 2013 & 2014 & 2015 & & & & \\
\hline Unia Europejska & 12,9 & 13,2 & 14,4 & 15,2 & 16,1 & 16,7 & 3,8 & 129 & 20 & $-3,3$ \\
\hline Austria & 30,4 & 30,6 & 31,4 & 32,3 & 32,8 & 33,0 & 2,6 & 109 & 34 & $-1,0$ \\
\hline Belgia & 5,7 & 6,3 & 7,2 & 7,5 & 8,0 & 7,9 & 2,2 & 139 & 13 & $-5,1$ \\
\hline Bułgaria & 14,1 & 14,3 & 16,0 & 19,0 & 18,0 & 18,2 & 4,1 & 129 & 16 & 2,2 \\
\hline Chorwacja & 25,1 & 25,4 & 26,8 & 28,0 & 27,9 & 29,0 & 3,9 & 116 & 20 & 9,0 \\
\hline Cypr & 6,0 & 6,0 & 6,8 & 8,1 & 8,9 & 9,4 & 3,4 & 157 & 13 & $-3,6$ \\
\hline Czechy & 10,5 & 11,0 & 12,8 & 13,8 & 15,1 & 15,1 & 4,6 & 144 & 13 & 2,1 \\
\hline Dania & 22,1 & 23,5 & 25,7 & 27,4 & 29,3 & 30,8 & 8,7 & 139 & 30 & 0,8 \\
\hline Estonia & 24,6 & 25,5 & 25,8 & 25,6 & 26,3 & 28,6 & 4,0 & 116 & 25 & 3,6 \\
\hline Finlandia & 32,4 & 32,8 & 34,4 & 36,7 & 38,7 & 39,3 & 6,9 & 121 & 38 & 1,3 \\
\hline Francja & 12,5 & 11,1 & 13,4 & 14,1 & 14,7 & 15,2 & 2,7 & 122 & 23 & $-7,8$ \\
\hline Grecja & 9,8 & 10,9 & 13,5 & 15,0 & 15,3 & 15,4 & 5,6 & 157 & 18 & $-2,6$ \\
\hline Hiszpania & 13,8 & 13,2 & 14,3 & 15,3 & 16,1 & 16,2 & 2,4 & 117 & 20 & $-3,8$ \\
\hline Holandia & 3,9 & 4,5 & 4,7 & 4,8 & 5,5 & 5,8 & 1,9 & 149 & 14 & $-8,2$ \\
\hline Irlandia & 5,6 & 6,6 & 7,2 & 7,7 & 8,7 & 9,2 & 3,6 & 164 & 16 & $-6,8$ \\
\hline Litwa & 19,6 & 19,9 & 21,4 & 22,7 & 23,6 & 25,8 & 6,2 & 132 & 23 & 2,8 \\
\hline Luksemburg & 2,9 & 2,9 & 3,1 & 3,5 & 4,5 & 5,0 & 2,1 & 172 & 11 & $-6,0$ \\
\hline Łotwa & 30,4 & 33,5 & 35,7 & 37,1 & 38,7 & 37,6 & 7,2 & 124 & 40 & $-2,4$ \\
\hline Malta & 1,0 & 1,9 & 2,8 & 3,7 & 4,7 & 5,0 & 4,0 & 500 & 10 & $-5,0$ \\
\hline Niemcy & 10,5 & 11,4 & 12,1 & 12,4 & 13,8 & 14,6 & 4,1 & 139 & 18 & $-3,4$ \\
\hline Polska & 9,3 & 10,3 & 10,9 & 11,4 & 11,5 & 11,8 & 2,5 & 127 & 15 & $-3,2$ \\
\hline Portugalia & 24,2 & 24,6 & 24,6 & 25,7 & 27,0 & 28,0 & 3,8 & 116 & 31 & $-3,0$ \\
\hline Rumunia & 23,4 & 21,4 & 22,8 & 23,9 & 24,8 & 24,8 & 1,4 & 106 & 24 & 0,8 \\
\hline Słowacja & 9,1 & 10,3 & 10,4 & 10,1 & 11,7 & 12,9 & 3,8 & 142 & 14 & $-1,1$ \\
\hline Słowenia & 20,4 & 20,3 & 20,8 & 22,4 & 21,5 & 22,0 & 1,6 & 108 & 25 & $-3,0$ \\
\hline Szwecja & 47,2 & 48,7 & 51,1 & 52,0 & 52,5 & 53,9 & 6,7 & 114 & 49 & 4,9 \\
\hline Węgry & 12,8 & 14,0 & 15,5 & 16,2 & 14,6 & 14,5 & 1,7 & 113 & 13 & 1,5 \\
\hline Wielka Brytania & 3,7 & 4,2 & 4,6 & 5,7 & 7,1 & 8,2 & 4,5 & 222 & 15 & $-6,8$ \\
\hline Włochy & 13,0 & 12,9 & 15,4 & 16,7 & 17,1 & 17,5 & 4,5 & 135 & 17 & 0,5 \\
\hline
\end{tabular}

1- różnica między 2015 r., a 2010 r. (w pkt. \%),

2 - $\mathrm{I}_{\mathrm{t} / 1}$ - współczynnik dynamiki dla 2015 r. (2010 r.=100\%),

3 - cel do osiągnięcia w 2020 r. (w \%),

${ }^{4}$ - różnica między wartością w 2015 r., a wartością celu wyznaczonego do osiągnięcia w 2020 r. (w pkt. \%).

Źródło: obliczenia własne na podstawie danych Eurostat, http://ec.europa.eu/eurostat [data dostępu: 30.04.2017]

$\mathrm{Na}$ podstawie danych zestawionych w tabeli 1 można stwierdzić, iż w $2015 \mathrm{r}$. największym udziałem energii ze źródeł odnawialnych w końcowym zużyciu energii brutto charakteryzowała się Szwecja $(53,9 \%)$. Tak wysoka wartość tego wskaźnika jest wynikiem konsekwentnie realizowanej $\mathrm{w}$ tym kraj, począwszy od lat 70. XX w., polityki ukierunkowanej na dywersyfikację źródeł pozyskiwanej energii oraz uniezależnienie się energetyczne zwłaszcza od wykorzystywania konwencjonalnych źródeł energii 
(OECD/IEA, 2013). Z kolei najmniejszym wskaźnikiem w omawianym zakresie, osiagającym udział w wysokości zaledwie 5\%, cechowały się Malta oraz Luksemburg.

Zestawienie prezentowanych danych z 2015 r. z krajowymi celami Strategii Europa 2020 w zakresie udziału energii ze źródeł odnawialnych w końcowym zużyciu energii brutto wykazała, iż tak postawione cele wypełniło już 11 państw członkowskich. Krajem, który na koniec 2015 r. był najbardziej oddalonym od postawionego celu w omawianym zakresie była Holandia. Dogłębna analiza postawionych celów i osiagniętych w poszczególnych latach przez badane państwa poziomów przyjętego wskaźnika pozwala na stwierdzenie, iż nie w przypadku wszystkich krajów głównym zakładanym celem jest poprawa omawianego wskaźnika. Należy zwrócić uwagę na Chorwację (przystapiła w 2013 r. do UE), w przypadku której docelowy udział energii ze źródeł odnawialnych w końcowym zużyciu energii brutto dla roku 2020 został wyznaczony na poziomie $20 \%$. Jest to wskaźnik znacznie poniżej osiąganych począwszy od 2010 roku przez ten kraj wartości omawianej zmiennej. Stąd też celem zasadniczym dla tego kraju jest utrzymanie tak wyznaczonej wartości docelowej.

$\mathrm{W}$ podejmowanych analizach należy również zwrócić uwagę, iż $\mathrm{w}$ przypadku wszystkich omawianych krajów na przestrzeni lat 2010-2015 wzrósł udział energii ze źródeł odnawialnych w końcowym zużyciu energii brutto. Stąd też można stwierdzić, iż powolne przejście na gospodarkę bardziej zrównoważoną pod względem energetycznym jest nie tylko czysto teoretycznym zapisem, ale już ma miejsce na obszarze UE. Najwyższą dynamiką analizowanego wskaźnika w badanym okresie charakteryzowały się Malta (500\%), Wielka Brytania (222\%) oraz Luksemburg (172\%). Pomimo wysokich wskaźników dynamiki Malta oraz Luksemburg podobnie jak w 2010 r., tak i w 2015 zajmowały dwie ostatnie pozycje pod względem udziału energii ze źródeł odnawialnych w końcowym zużyciu energii brutto wśród państw UE-28. Z kolei najniższą dynamiką pod względem analizowanego w tabeli 1 wskaźnika cechowała się Rumunia (106\%). Analiza przedstawionych danych pozwala na stwierdzenie, iż w latach 2010-2015 nastapił 29\% przyrost udziału energii ze źródeł odnawialnych w końcowym zużyciu energii brutto na obszarze Unii Europejskiej.

Omówiona wyżej zmienna jest znacznie szerszym obszarem badawczym niż przyjęty w artykule, gdyż oprócz energii elektrycznej uwzględnia również inne rodzaje energii, które pozyskiwane są ze źródeł odnawialnych (np. energię cieplną). Niemniej jednak bez omówienia tych informacji i przyczyn wzrostu zainteresowania pozyskiwaniem energii ze źródeł odnawialnych w UE nie sposób dalej podejmować analiz już wyłącznie w obszarze energii elektrycznej. Dane w tym zakresie prezentuje tabela 2 . Na jej podstawie można stwierdzić, iż w latach 2010-2015 na obszarze UE nastąił 46\% przyrost udziału energii elektrycznej wytwarzanej ze źródeł odnawialnych w zużyciu energii elektrycznej brutto. Największą dynamiką w tym zakresie charakteryzowały się Cypr (600\%), Wielka Brytania (303\%) oraz Belgia $(217 \%)$. W tym miejscu należy również zwrócić uwagę na sytuację Malty, w której w 2010 r. nie definiowano udziału energii elektrycznej wytwarzanej ze źródeł odnawialnych w zużyciu energii elektrycznej brutto (brak lub też znikomy poziom udziału), a w 2015 r. był on już na poziomie 4,2\%. Najniższym z kolei wskaźnikiem dynamiki cechowała się Słowenia (102\%). Również na podstawie danych zawartych $\mathrm{w}$ tabeli 2 można stwierdzić, iż w 2015 r. w każdym państwie UE udział energii elektrycznej wytwarzanej ze źródeł odnawialnych w zużyciu energii elektrycznej brutto był wyższy niż w $2010 \mathrm{r}$. 
Tabela 2. Udział energii elektrycznej wytwarzanej ze źródeł odnawialnych w zużyciu energii elektrycznej brutto w \% w państwach UE-28 w latach 2010-2015

Table 2 . Share of electricity produced from renewable sources in gross electricity consumption in \% in EU-28 in 2010-2015

\begin{tabular}{|c|c|c|c|c|c|c|c|c|}
\hline \multirow[t]{2}{*}{ Wyszczególnienie } & \multicolumn{6}{|c|}{$\begin{array}{l}\text { Udział energii elektrycznej wytwarzanej ze } \\
\text { źródeł odnawialnych w zużyciu energii } \\
\text { elektrycznej brutto w \% w roku: }\end{array}$} & \multirow[t]{2}{*}{ Zmiana $^{1}$} & \multirow[t]{2}{*}{$\mathrm{I}_{\mathrm{t} / 1}^{2}$} \\
\hline & 2010 & 2011 & 2012 & 2013 & 2014 & 2015 & & \\
\hline Unia Europejska & 19,7 & 21,7 & 23,5 & 25,4 & 27,5 & 28,8 & 9,1 & 146 \\
\hline Austria & 65,7 & 66,0 & 66,5 & 68,0 & 70,1 & 70,3 & 4,6 & 107 \\
\hline Belgia & 7,1 & 9,1 & 11,3 & 12,5 & 13,4 & 15,4 & 8,3 & 217 \\
\hline Bułgaria & 12,7 & 12,9 & 16,1 & 18,9 & 18,9 & 19,1 & 6,4 & 150 \\
\hline Chorwacja & 37,6 & 37,6 & 38,8 & 42,1 & 45,3 & 45,4 & 7,8 & 121 \\
\hline Cypr & 1,4 & 3,4 & 4,9 & 6,6 & 7,4 & 8,4 & 7,0 & 600 \\
\hline Czechy & 7,5 & 10,6 & 11,7 & 12,8 & 13,9 & 14,1 & 6,6 & 188 \\
\hline Dania & 32,7 & 35,9 & 38,7 & 43,1 & 48,5 & 51,3 & 18,6 & 157 \\
\hline Estonia & 10,4 & 12,3 & 15,8 & 13,0 & 14,1 & 15,1 & 4,7 & 145 \\
\hline Finlandia & 27,7 & 29,4 & 29,5 & 30,9 & 31,4 & 32,5 & 4,8 & 117 \\
\hline Francja & 14,8 & 16,3 & 16,4 & 16,9 & 18,3 & 18,8 & 4,0 & 127 \\
\hline Grecja & 12,3 & 13,8 & 16,4 & 21,2 & 21,9 & 22,1 & 9,8 & 180 \\
\hline Hiszpania & 29,8 & 31,6 & 33,5 & 36,7 & 37,8 & 36,9 & 7,1 & 124 \\
\hline Holandia & 9,6 & 9,8 & 10,4 & 10,0 & 10,0 & 11,1 & 1,5 & 116 \\
\hline Irlandia & 14,6 & 17,4 & 19,7 & 21,0 & 22,9 & 25,2 & 10,6 & 173 \\
\hline Litwa & 7,4 & 9,0 & 10,9 & 13,1 & 13,7 & 15,5 & 8,1 & 209 \\
\hline Luksemburg & 3,8 & 4,1 & 4,6 & 5,3 & 5,9 & 6,2 & 2,4 & 163 \\
\hline Łotwa & 42,1 & 44,7 & 44,9 & 48,8 & 51,1 & 52,2 & 10,1 & 124 \\
\hline Malta & 0,0 & 0,5 & 1,1 & 1,6 & 3,3 & 4,2 & 4,2 & - \\
\hline Niemcy & 18,1 & 20,9 & 23,6 & 25,3 & 28,2 & 30,7 & 12,6 & 170 \\
\hline Polska & 6,6 & 8,2 & 10,7 & 10,7 & 12,4 & 13,4 & 6,8 & 203 \\
\hline Portugalia & 40,7 & 45,9 & 47,6 & 49,1 & 52,1 & 52,6 & 11,9 & 129 \\
\hline Rumunia & 30,4 & 31,1 & 33,6 & 37,5 & 41,7 & 43,2 & 12,8 & 142 \\
\hline Słowacja & 17,8 & 19,3 & 20,1 & 20,8 & 22,9 & 22,7 & 4,9 & 128 \\
\hline Słowenia & 32,2 & 31,0 & 31,6 & 33,1 & 33,9 & 32,7 & 0,5 & 102 \\
\hline Szwecja & 56,0 & 59,9 & 60,0 & 61,8 & 63,2 & 65,8 & 9,8 & 118 \\
\hline Węgry & 7,1 & 6,4 & 6,1 & 6,6 & 7,3 & 7,3 & 0,2 & 103 \\
\hline Wielka Brytania & 7,4 & 8,8 & 10,7 & 13,8 & 17,9 & 22,4 & 15,0 & 303 \\
\hline Włochy & 20,1 & 23,5 & 27,4 & 31,3 & 33,4 & 33,5 & 13,4 & 167 \\
\hline
\end{tabular}

1 - różnica między 2015 r., a 2010 r. (w pkt. \%),

${ }^{2}-\mathrm{I}_{\mathrm{t} / 1}-$ współczynnik dynamiki dla 2015 r. (2010 r.=100\%).

Źródło: obliczenia własne na podstawie danych Eurostat, http://ec.europa.eu/eurostat [data dostępu: 30.04.2017].

Przedstawione dane potwierdzają dynamicznie zachodzącą transformację w kierunku zrównoważonego rozwoju w sektorze produkcji energii elektrycznej. W 2015 r. w przypadku pięciu państw zaobserwowano ponad 50\% udział energii elektrycznej wytwarzanej ze źródeł odnawialnych w zużyciu energii elektrycznej brutto, były to: Austria $(70,3 \%)$, Szwecja $(65,8 \%)$, Portugalia $(52,6 \%)$, Lotwa $(52,2 \%)$ oraz Dania $(51,3 \%)$ 
Państwa te od wielu lat prowadzą politykę energetyczną ukierunkowaną na pozyskiwanie energii ze źródeł odnawialnych (https://www.iea.org/, dostęp: 14.04.2017 r.).

\section{Produkcja energii elektrycznej ze źródeł odnawialnych w Polsce - ujęcie regionalne}

Polska jest krajem charakteryzującym się, na tle pozostałych państw członkowskich UE, jednym $\mathrm{z}$ najniższych udziałów energii elektrycznej wytwarzanej ze źródeł odnawialnych w zużyciu energii elektrycznej brutto. Należy zauważyć również, iż sytuacja ta nie ulegnie zasadniczemu polepszeniu nawet przy spełnieniu wyznaczonego $\mathrm{w}$ tym zakresie indywidualnego celu na rok 2020 (tab. 1). Jak prezentuje z kolei tabela 3 produkcja energii elektrycznej ze źródeł odnawialnych w Polsce znacząc wzrosła na przestrzeni lat 2010-2015 (przyrost o 108\% względem 2010 r.).

Tabela 3. Produkcja energii elektrycznej ze źródeł odnawialnych w Polsce w układzie regionalnym w latach 20102015 w GWh

Table 3. Production of electricity from renewable sources in Poland in the regional system in 2010-2015 in GWh

\begin{tabular}{|c|c|c|c|c|c|c|c|c|}
\hline \multirow[t]{2}{*}{ Wyszczególnienie } & \multicolumn{6}{|c|}{$\begin{array}{l}\text { Produkcja energii elektrycznej ze źródeł odnawialnych } \\
\text { w GWh w roku: }\end{array}$} & \multirow[t]{2}{*}{$Z_{\text {miana }}{ }^{1}$} & \multirow[t]{2}{*}{$\mathrm{I}_{\mathrm{t} / 1}^{2}$} \\
\hline & 2010 & 2011 & 2012 & 2013 & 2014 & 2015 & & \\
\hline Polska & 10888,8 & 13136,9 & 16878,9 & 17066,6 & 19841,2 & 22675,4 & 11786,6 & 208 \\
\hline Dolnośląskie & 658,9 & 703,5 & 897,0 & 763,1 & 1055,9 & 1013,0 & 354,1 & 154 \\
\hline Kujawsko-pomorskie & 2098,2 & 2063,3 & 1865,8 & 2148,1 & 2212,6 & 2558,2 & 460,0 & 122 \\
\hline Lubelskie & 14,5 & 18,3 & 31,8 & 47,7 & 55,1 & 95,2 & 80,7 & 657 \\
\hline Lubuskie & 197,1 & 191,2 & 287,5 & 312,1 & 290,9 & 360,4 & 163,3 & 183 \\
\hline Łódzkie & 429,8 & 603,0 & 1165,1 & 953,0 & 927,2 & 1223,3 & 793,5 & 285 \\
\hline Małopolskie & 783,8 & 868,6 & 886,3 & 480,7 & 590,8 & 463,1 & $-320,7$ & 59 \\
\hline Mazowieckie & 1010,6 & 1194,1 & 1698,5 & 1800,1 & 1982,7 & 1872,1 & 861,5 & 185 \\
\hline Opolskie & 269,6 & 308,8 & 340,6 & 444,2 & 558,3 & 628,2 & 358,6 & 233 \\
\hline Podkarpackie & 315,7 & 319,7 & 342,5 & 394,6 & 459,8 & 574,1 & 258,4 & 182 \\
\hline Podlaskie & 236,3 & 388,9 & 435,3 & 600,0 & 654,7 & 850,7 & 614,4 & 360 \\
\hline Pomorskie & 770,1 & 1002,3 & 1215,8 & 1343,8 & 1550,0 & 1949,3 & 1179,2 & 253 \\
\hline Śląskie & 1519,7 & 1678,1 & 2223,7 & 1548,9 & 1761,5 & 1597,5 & 77,8 & 105 \\
\hline Świętokrzyskie & 821,6 & 883,9 & 1265,7 & 1745,2 & 2416,4 & 2717,2 & 1895,6 & 331 \\
\hline Warmińsko-mazurskie & 137,5 & 452,1 & 554,8 & 549,8 & 746,0 & 949,6 & 812,1 & 691 \\
\hline Wielkopolskie & 927,6 & 1009,5 & 1319,3 & 1280,6 & 1489,9 & 1957,5 & 1029,9 & 211 \\
\hline Zachodniopomorskie & 697,6 & 1451,7 & 2349,3 & 2654,6 & 3089,7 & 3866,1 & 3168,5 & 554 \\
\hline
\end{tabular}

Źródło: obliczenia własne na podstawie danych Banku Danych Lokalnych, https://bdl.stat.gov.pl/BDL/start [data dostępu: 30.04.2017].

Z kolei analiza regionalna pozwala na wskazanie, iż we wszystkich województwach oprócz woj. małopolskiego nastąpił wzrost produkcji energii elektrycznej ze źródeł odnawialnych w 2015 r. w porównaniu z 2010 r. Należy przy tym wskazać, iż najwyższą dynamiką analizowanego wskaźnika w badanym okresie charakteryzowały się woj. 
warmińsko-mazurskie (691\%), woj. lubelskie (657\%) oraz woj. zachodniopomorskie (554\%). Z kolei do największego wzrostu w liczbie produkowanych GWh ze źródeł odnawialnych, w ciągu pięciu omawianych lat, doszło w następujących województwach: zachodniopomorskim (wzrost o 3168,5 GWh), świętokrzyskim (wzrost o 1895,6 GWh) oraz pomorskim (wzrost o 1179,2 GWh).

Przy omawianiu poruszanej w niniejszym artykule problematyki warto również przytoczyć dane dotyczące udziału produkcji energii elektrycznej ze źródeł odnawialnych w produkcji energii elektrycznej ogółem (tab. 4). Wskaźnik ten pozwala na wskazanie, czy wcześniej zanalizowany i potwierdzony dynamiczny wzrost produkcji energii elektrycznej z odnawialnych źródeł energii rzeczywiście wskazuje na stopniowe przechodzenie gospodarki polskiej na bardziej zrównoważony niż dotychczas sposób pozyskiwania energii elektrycznej.

Tabela 4. Udział produkcji energii elektrycznej ze źródeł odnawialnych w produkcji energii elektrycznej ogółem w Polsce z uwzględnieniem województw w latach 2010-2015 w \%

Table 4. Share of electricity from renewable sources in total electricity production in Poland, including voivodeships in $2010-2015$ in \%

\begin{tabular}{|c|c|c|c|c|c|c|c|c|}
\hline \multirow{2}{*}{$\begin{array}{c}\text { Polska/ } \\
\text { Województwo }\end{array}$} & \multicolumn{6}{|c|}{$\begin{array}{l}\text { Udział produkcji energii elektrycznej ze źródeł odnawialnych w } \\
\text { produkcji energii elektrycznej ogółem w \% w roku: }\end{array}$} & \multirow[t]{2}{*}{ Zmiana $^{1}$} & \multirow[t]{2}{*}{$\mathrm{I}_{\mathrm{t} / 1}^{2}$} \\
\hline & 2010 & 2011 & 2012 & 2013 & 2014 & 2015 & & \\
\hline Polska & 6,9 & 8,0 & 10,4 & 10,4 & 12,5 & 13,7 & 6,8 & 199 \\
\hline Dolnośląskie & 4,9 & 5,3 & 6,6 & 6,0 & 9,6 & 9,4 & 4,5 & 192 \\
\hline Kujawsko-pomorskie & 59,0 & 60,5 & 58,7 & 63,1 & 65,8 & 68,6 & 9,6 & 116 \\
\hline Lubelskie & 0,8 & 0,9 & 1,5 & 3,8 & 4,4 & 5,3 & 4,5 & 663 \\
\hline Lubuskie & 8,6 & 8,0 & 11,4 & 12,3 & 11,6 & 14,4 & 5,8 & 167 \\
\hline Łódzkie & 1,5 & 1,8 & 3,3 & 2,6 & 2,5 & 3,3 & 1,8 & 220 \\
\hline Małopolskie & 11,4 & 12,4 & 13,9 & 7,2 & 9,5 & 7,0 & $-4,4$ & 61 \\
\hline Mazowieckie & 4,5 & 5,3 & 7,7 & 7,8 & 8,3 & 7,9 & 3,4 & 176 \\
\hline Opolskie & 3,0 & 3,4 & 4,0 & 5,1 & 6,4 & 7,6 & 4,6 & 253 \\
\hline Podkarpackie & 11,9 & 11,1 & 12,9 & 16,1 & 23,4 & 19,8 & 7,9 & 166 \\
\hline Podlaskie & 37,5 & 48,8 & 60,2 & 72,3 & 69,8 & 70,1 & 32,6 & 187 \\
\hline Pomorskie & 25,0 & 30,8 & 35,5 & 36,6 & 41,3 & 45,9 & 20,9 & 184 \\
\hline Śląskie & 4,7 & 5,1 & 7,1 & 5,0 & 6,6 & 5,8 & 1,1 & 123 \\
\hline Świętokrzyskie & 9,3 & 10,4 & 15,3 & 22,2 & 26,2 & 27,5 & 18,2 & 296 \\
\hline Warmińsko-mazurskie & 38,8 & 70,6 & 74,4 & 72,3 & 78,7 & 83,4 & 44,6 & 215 \\
\hline Wielkopolskie & 7,3 & 7,8 & 10,1 & 9,4 & 11,3 & 14,6 & 7,3 & 200 \\
\hline Zachodniopomorskie & 8,8 & 16,4 & 27,0 & 30,4 & 35,1 & 38,6 & 29,8 & 439 \\
\hline
\end{tabular}

- różnica między 2015 r., a 2010 r. (w pkt. \%),

${ }^{2}-\mathrm{I}_{\mathrm{t} / 1}-$ współczynnik dynamiki dla 2015 r. $(2010$ r.=100\%).

Źródło: obliczenia własne na podstawie Banku Danych Lokalnych.

Dane zaprezentowane w tabeli 4 wskazują, iż w latach 2010-2015 doszło do wzrostu udziału energii elektrycznej wytwarzanej ze źródeł odnawialnych w ogólnej produkcji energii elektrycznej (zarówno ze źródeł konwencjonalnych, jak i niekonwencjonalnych). Z kolei analiza regionalnego zróżnicowania omawianej zmiennej pozwala na wskazanie, iż w przypadku trzech województw w 2015 r. produkcja energii elektrycznej na ich obszarze 


\section{E. Kozar}

w ponad $50 \%$ oparta była na odnawialnych źródłach energii. Były to następujące województwa: warmińsko-mazurskie, podlaskie, kujawsko-pomorskie.

Najwyższą dynamiką produkcji energii elektrycznej ze źródeł odnawialnych w produkcji energii elektrycznej ogółem w badanym okresie charakteryzowały się woj. lubelskie (663\%), woj. zachodniopomorskie (439\%) oraz woj. świętokrzyskie (296\%). Biorąc pod uwagę analizowaną w tabeli 4 zmienną należy wskazać również to, że jedynie w przypadku woj. małopolskiego doszło do jej spadku (spadek o 39\%). Z kolei udział energii elektrycznej wytwarzanej $\mathrm{z}$ odnawialnych źródeł energii $\mathrm{w}$ produkcji energii elektrycznej ogółem w pierwszych pięciu latach obowiązywania Strategii Europa 2020 cechował się w Polsce aż 99\% przyrostem (nastąpiło niemalże podwojenie wyjściowej wartości). Stanowi to kolejne istotne podkreślenie zmian zachodzących w produkcji energii elektrycznej w Polsce ukierunkowanej na zrównoważony rozwój energetyczny kraju.

\section{Podsumowanie}

Udział energii elektrycznej wytwarzanej ze źródeł odnawialnych w zużyciu energii elektrycznej brutto w krajach Unii Europejskiej cechował się 46\% przyrostem w latach 2010-2015. W żadnym z omawianych państw w tym zakresie nie nastąpił spadek. Fakt ten świadczy, iż w każdym kraju UE zachodzą obecnie intensywne zmiany ukierunkowane na budowę bardziej ekologicznego, a więc sprzyjającej środowisku naturalnemu gospodarki. Taki model gospodarowania będzie $\mathrm{w}$ większym niż dotychczas stopniu oparty na pozyskiwaniu energii (w tym energii elektrycznej) ze źródeł odnawialnych. Nie sposób bowiem w obecnie rozwiniętych gospodarkach zaprzestać produkcji energii mimo negatywnych oddziaływań procesów produkcyjnych na środowisko naturalne (zwłaszcza tych związanych z konwencjonalnymi źródłami energii).

W przypadku Polski również widoczne są już istotne zachodzące zmiany ukierunkowane na zrównoważony rozwój w obszarze związanym z pozyskiwaniem energii. W pierwszej kolejności należy zauważyć, iż w analizowanym okresie nastapił tutaj przyrost udziału energii elektrycznej wytwarzanej ze źródeł odnawialnych w zużyciu energii elektrycznej brutto. Przyrost ten wyniósł $103 \%$ i był jedną z najbardziej dynamicznych zmian na tle pozostałych analizowanych państw UE. Warto w tym miejscu zwrócić również szczególną uwagę na postępujący proces wzrostu produkcji energii elektrycznej z odnawialnych źródeł energii. Istotne także staje się zauważenie, iż wzrost produkcji energii elektrycznej $\mathrm{z}$ odnawialnych źródeł energii przekłada się na wzrost udziału wytwarzanej tego typu energii elektrycznej w produkcji energii elektrycznej ogółem.

Należy w tym miejscu wskazać ponadto, iż wzrost energii elektrycznej pozyskiwanej z odnawialnych źródeł energii, poza mniejszym w porównaniu do konwencjonalnych źródeł energii negatywnym wpływem na środowisko naturalne, przełożyć może się na poprawę bezpieczeństwa energetycznego kraju. Tak więc faktyczny wzrost udziału w zużyciu energii elektrycznej ze źródeł odnawialnych może przyczyniać się do stopniowego wdrażania idei zrównoważonego rozwoju w życie społeczno-gospodarcze w danym kraju. W sposób szczególny w najbliższych latach może być to zauważalne w Polsce, gdzie produkcja energii elektrycznej w głównej mierze oparta jest na konwencjonalnych źródłach energii (węglu kamiennym oraz brunatnym). Rezygnacja $\mathrm{z}$ tego typu źródeł energii i przechodzenie na odnawialne może przyczynić się w Polsce nie tylko do poprawy jakości powietrza, ale również do istotnych zmian $\mathrm{w}$ zakresie rynku pracy. $\mathrm{W}$ tym ostatnim 
zakresie chodzi przede wszystkim o tworzenie tzw. „zielonych” miejsc pracy w sektorze energetyki odnawialnej (Kozar, 2015).

\section{Literatura}

Ang, B. W., Choong, W. L., Ng, T. S. (2015). Energy security: Definitions, dimensions and indexes. Renewable and Sustainable Energy Reviews, 42, 1077-1093.

Banku Danych Lokalnych, https://bdl.stat.gov.pl/BDL/start, Dane pobrano 30 kwietnia 2017.

Europa 2020. Strategia na rzecz inteligentnego i zrównoważonego rozwoju sprzyjającego włączeniu społecznemu, KOM(2010) 2020 final, Pobrane 25 kwietnia 2017 z: http://eurlex.europa.eu/LexUriServ/LexUriServ. do?uri=COM:2010:2020:FIN:PL:PDF

Eurostatu, http://ec.europa.eu/eurostat, Dane pobrano 30 kwietnia 2017.

https://www.iea.org/, (dostęp: 14.04.2017 r.,)

Kozar, Ł. (2015). „Zielone” miejsca pracy jako efekt dążeń do zrównoważonego rozwoju społecznogospodarczego, Rynek-Spoleczeństwo-Kultura, 3, 5-11.

Lior, N. (2008). Energy resources and use: the present situation and possible paths to the future. Energy, 33(6), $842-857$.

Malko, J., Wilczyński, A., Wojciechowski, H. (2015). Bezpieczeństwo energetyczne, dostępność energii i zrównoważony rozwój a strategia unii energetycznej. Rynek Energii, 2(117), 10-17.

OECD/IEA (2013). Energy Policies of IEA Countries - Sweden 2013 Review. International Energy Agency, Paris.

Poskrobko, B. (2009). Wpływ trendów społecznych i gospodarczych na implementacje idei zrównoważonego rozwoju. W: Zrównoważony rozwój gospodarki opartej na wiedzy, B. Poskrobko (red.). Wydawnictwo Wyższej Szkoły Ekonomicznej w Białymstoku, Białystok, 108-126.

Qureshi, M. I., Rasli, A. M., Zaman, K. (2016). Energy crisis, greenhouse gas emissions and sectoral growth reforms: Repairing the fabricated mosaic. Journal of Cleaner Production, 112, 3657-3666.

Ryszawska, B. (2013). Zielona gospodarka - teoretyczne podstawy koncepcji i pomiar jej wdrażania w Unii Europejskiej. Wydawnictwo Uniwersytetu Ekonomicznego we Wrocławiu, Wrocław.

Suppes, G. J., Storvick, T. S. (2016). Energy and Civilization. W: Sustainable Power Technologies and Infrastructure: Energy Sustainability and Prosperity in a Time of Climate Change, G. J. Suppes (red.), T. S. Storvick (red.). Academic Press, 1-28.

Szałata, Ł., Siedlecka, A., Lejkowski, C. (2016). Instalacje fotowoltaiczne jako przykład uzasadnionej ekonomicznie działalności prosumenckiej. Ekonomia i Środowisko, 2(57), 190-205.

Twidell, J., Weir, T. (2015). Renewable energy resources. Routledge Taylor \& Francis Group, London, 14-17.

Zaman, K., Abd-el Moemen, M. (2017). Energy consumption, carbon dioxide emissions and economic development: Evaluating alternative and plausible environmental hypothesis for sustainable growth. Renewable and Sustainable Energy Reviews, 74, 1119-1130. 